\title{
How to Know This Is a Good Thing: \\ A Developmental Analysis of \\ Inter-Cultural, Anti-Racist Education
}

\section{Ronnie F. Blakeney}

The tension between cultural pluralism and social cohesion is perhaps the single most resonant moral paradox for contemporary democracies. The challenge is no less daunting for public education. In the past forty years $\mathrm{N}$ orth American projects for Intercultural and Anti-racist education have had limited success. This paper argues that such projects have suffered from an unclear moral vision and from a pedagogical indifference to the devel opmental stages of children and adolescentsas learners. Thispaper describes two distinct moral aims of education for democratic citizenship. It argues that the tension between the two approaches can be resolved by reference to the developmental needs of various groups of learners. A developmental approach to Inter-Cultural, Anti-racist Education is outlined.

The Roots of Inter-cultural, Anti-Racist Education in Northern Californi a

O $n$ the border where Berkeley, California meets $\mathrm{O}$ akland, near the San Francisco Bay, there is a small brick building, barely large enough to house its wood burning barbecue. Its chimney bellows with the spicy smell of Flint's BBQ . O n weekends, colorful lines of U niversity of California at Berkeley students and East Bay African-American families crowd the sidewalks, jostling and joking, waiting for their barbecue orders. A boom box ${ }^{1}$ blares Bob M arley warning us that we're living in Babylon.

In 1968 the Black Panther Party opened its Free Press in a storefront adjacent to Flint's. Students from both sides of the line demanded «relevant» education. It was a time when $M$ artin Luther King told us that men shouldn't be judged by the color of their skin, but by the content of their character (King, 1968), graduate schools of education began to reform curriculum (Katz, 1983; Weinberg, 1977) and M ario Savio and D aniel Cohn Bendit called for free speech and revolution. Ronald Reagan called in the N ational Guard to shoot students on the 
Berkeley campus, and yellow school busses crossed invisible racial barriers to end race-based injustice in public schooling. It was al so a time when James Brown, the King of Soul music, shouted out loud, I'm Black and I'm Proud.

It was the year I got my credential - number 002 - to teach «American Ethnic Studies» in California. Those of us who marched, sat in, negotiated, and, finally, demanded to be included - believed that education was the path to social justice within a democracy (C armichael \& $\mathrm{H}$ amilton, 1967; Perkinson, 1968).

In the 1960's we educators were convinced that if we taught children about each other's cultures and values (Banks \& Lynch, 1986); and if we taught them respect and communication and if we included the art, literature, history, and philosophy of all people (Tyack, 1974); - and especially of all Americans - then the vicious racism that enslaved us all would die out in two generations (Katz, 1983). M aybe we were naïve about the timing.

\section{Conflicting Moral Ai ms of Education in Plural Democracies}

The tension between respect for cultural pluralism, on the one hand and social cohesion on the other is the single most resonant moral question for increasingly more contemporary democracies (Blakeney, 2000; Castles \& Davidson, 2000; $N$ ieto, 2000). The question of the color line is no less a question in contemporary Britain at the start of the 21st century than it was for the US and colonial Africa at the start of the last century (D uBois, 1903/1961). The ideals of pluralism daily fall to the pragmatics of politics or peace. Kosovo, Israel, Rwanda, Kashmir and Peru are only recent examples. The way a given nation balances cultural pluralism with liberal democracy defines it. The tension between the universal and the particulars defines the essential characteristics that mark our integrity as a nation , and the moment when we cease to be us. It outlines the narrative that defines our history as a people, and specifies our commitment to a shared future as citizens (Gibson \& O gbu, 1991). When a substantial percentage of a population in a given nation has a dual identity based on the above criteria, the nation's goals with respect to integration, assimilation, accommodation, and so on, become a central question for a democracy, and, as a consequence, for its public schooling. W hat/ whose history, values, literature, art, music, epistemology and customs will we teach and through what/whose perspective?

Recent educational research, theory and practice demonstrate that inter-cultural and anti-racist education continues to be a concern in N orth America and, increasingly, internationally (Suarez-O rozco, 2001). D espite the attention paid to inter-cultural and anti-racist education, and despite the critical need to find effective ways to educate children for inter-cultural respect in contemporary democracies, too few of the reported projects effectively meet their goals ( $M$ ay, 1999). 
The failure of multi-cultural education to solve the problems of fratricide, genocide and despotism.

Much of what is called ethnic studies, multi/inter-cultural education, anti-racist pedagogy, tolerance training, pluralist and peace education, and so on suffers from 1.) a murky moral vision, and 2.) a failure to attend to basic pedagogical principles derived from an understanding of child development. In Part O ne of this paper, I argue that two streams of democratic moral education give rise to two distinct and sometimes contradictory goals for Inter-cultural and anti-racist education. How do we address the tension that arises when an orientation to procedural, abstract visions of justice, in the sense of Rawls (1971) and Kohlberg (1986) come in conflict with the cultural and situational particulars demanded by post-structuralist approaches to education (cf. Gilligan, Lyons \& Hanmer, 1990). In Part Two, I suggest that applying developmental principles to programs of intercultural anti-racist education guides educators between the rock of moral absolutism (which taunts freedom $\&$ democracy) and the hard place of moral relativism (which bedevils advocates of tolerance and peace).

The Moral Confounding of I nter-cultural

Anti-racist Education

Phil osophies of Education: Two streams

$H$ istorical foundations of Inter -Cultural anti-Racist E ducation (ICARE)

Pluralist approaches to public education in European and North American Schools derive haphazardly from two long standing, respected educational traditions: Cultural Transmission (CT) and Civic Education (CE).

The first tradition, CT, is as ubiquitous as cultivation. It looks to schooling primarily for its role in cultural continuity. Instruction is designed so that children will master the accumulated wisdom and cultural expectations of the society in which they will become adults. This tradition is no more tied to BF Skinner (1953), Watson (1930) and the behaviorists than it is to Banks (1994) or Vygotsky (1978).

The second paradigm, CE, is as old as public schooling itself. It sees the role of schooling as preparing young people for citizenship in a democratic society. $C E$ is both an American norm (since at least the time of D ewey) and a process for establishing and maintaining democratic citizenship (cf. Freire, 1973).

On the surface, CT and CE are logically and practically compatible. Through Cultural Transmission, children are taught the lessons of (our collective) past, so that, through Civic Education, they can carry that message forward as adults, citizens and equal members in a democratic society.

The Cultural Transmission path to plural ism In many communities, and indeed in much of the world before the twentieth 
century, CT was a reasonable mode of preparing children for full participation as adults, in the society of their parents. CT might reasonably include both a 3Rs Back to Basics approach to schooling, and Black Studies programs that teach $R e-$ sistance as Resilience. A Japanese $\mathrm{N}$ obel chemist recently concluded that Japan produces few $\mathrm{N}$ obel laureates because its educational system is based on the need to build synchronous teams, people who work together and share water equally for optimum cultivation of rice. The transmission of values within Japanese culture favors the collective good over individual initiative; tradition over creativity; authority over innovation. It produces broad excellence and limited rebellion (N Y Times, 2001).

The Civic Education Path through PI ural ism

The CE paradigm presumes that in a democracy, we must educate all children to read and write; to think critically and to be prepared for responsible participation in social, political and economic arenas (O ser, Dick \& Patry, 1992). CE, in its orientation toward social justice, also implies addressing questions of equal access to full participation in economic and civic life; issues of dominance and oppression; inclusion and exclusion, etc.

The moral tension between Civic Education and PI ural ism CE and CT are generally compatible as applied to curriculum or pedagogy for children and adolescents in primary and secondary schools. Swiss children, Japanese children, British children, French children, for example, have been reared in the traditions of their respective cultures, to be responsible and effective citizens of their respective democratic nations.

Recently, however, it became increasingly apparent in the U S, in Latin America and in the post-colonial world, that educating for justice, for full participation in democratic civic life, raised questions of both knowledge and praxis (cf. $\mathrm{H}$ aste, 2001).

1. «W ho's culture» is being transmitted by the schools?

2. At whose behest? and,

3. Toward who's common good?

Domi nance concealed i $n$ Democracy

In his $\mathrm{H}$ arvard Education Review article «D ominance Concealed through $\mathrm{Di}$ versity,» my colleague D wight Boyd (Boyd, 1996) wrote that the dilemma of diversity, particularly as it applies to public education, «lies at the heart of the moral cohesion of any society that strives to take its commitments to diversity seriously.» Boyd outlined three approaches to cultural plural ism, which, he argued, were inadequate to the task of preparing children for adult citizenship in diverse democracies, because they avoided addressing the dilemma of dominance. The question, as he poses it, is who defines the good society and the good person, the moral ideal of any system of public education. 
Put another way, schools have as their goal, their hidden curriculum (Kohlberg, 1986) an implicit understanding of instructors as moral educators. While any of us may disagree about what constitutes «the good,» few would argue that a public school was designed to achieve ends which its developers and proponents thought of as Bad for children or for society.

«C aning» for example, might be anathema to modern, liberals, but from the point of view of its proponents, C aning is an effective and appropriate means to foster diligence, discipline, and respect for authority, all necessary for good individual and social development. Vocational training and «Classical» (liberal arts) education have enjoyed periods of popularity and periods of disfavor; gender separate and gender mixed schooling, similarly. Proponents on either side argue, fairly, that their point of view is best for the children and best for society.

From this perspective, we might all agree that education is a moral enterprise. Schooling can be likened to a guided tour, where the job of the «agent» is to find the best route to a good end, mutually agreed on by the constituents whose children are to be entrusted to society's tour guide.

W ith changing borders, cross-border travel, immigration, post-colonial, technological work communities, refugees, ancient and modern ethnic conflicts, mass migrations and world-wide web speed communication, public schools must address a difficult moral question: «H ow do we account for potentially conflicting definitions of the educational $\mathrm{G}$ ood that inheres in pluralist democracies?»

As educators, we are charged with preparing young people for citizenship. In pluralist democracies, we bring inter-cultural anti-racist education into our classrooms, schools, and teacher training; into our educational research and our program evaluation. Yet, how can we make responsible educational decisions given an ever-shifting moral vision? Are we educators preparing today's children for tomorrow's soup? Or for tomorrow's salad? W ill a feminist pedagogy or math for girls raise the consciousness, confidence and competence of girls, (and hence «equality») or does it foster inter-gender division, competition and disharmony? What about bilingual, bicultural education? Affirmative action? Are there guidelines for selecting and evaluating curriculum which prepare children for pluralist democracies without either forcing a personal (idiosyncratic) moral vision on our students or, al ternately, falling into the morass of moral neutrality?

The Aim of Inter-cultural and Anti-Racist

Education

The ai m of I ntercultural Education Inter-cultural Projects are those designed to extend the knowledge base of learners to include the experiences (history, literature, art, music, customs, social life, values) and perspectives of people whose experiences and perspectives differ 
from their own (cf. Gollnick, 1980; Sleeter \& Grant, 1987). Such programs emphasize mutual respect and inter-cultural (as well as interpersonal) understanding. They are based on the assumption that if we know more about each other, we will «get along» better; that respect is an antidote for injustice; that education reduces fear and hence prejudice and hence discrimination, retaliation, etc. Its goal is to reduce intergroup antipathy and fear while celebrating diversity. Its moral vision is a multi-cultural mosaic, each group in its own line, singing its own song, telling its own stories.

The aim of Anti-racist Education

Anti-racist education, while it may share some of the aims of inter-cultural education, makes primary an awareness of the hierarchical nature of prejudice and discrimination (Pacheco, 1977; Suzuki, 1984), and addresses issues of dominance and oppression, regardless of cultural differences, as the primary evil to be identified and rooted out (D erman-Sparks, ABC Task force 1998). Anti-racist education may use inter-cultural approaches to achieve its ends of a just and free society, but its goal is the end of oppression, even if it means obliterating cultural pluralism. It's moral vision is merging the clusters of people at Flint's Barbecue Take-out into one line, each individual waiting her/his turn to choose ribs, chicken, beef - or tofu.

Intercultural education and anti-racist education differ not so much in their definition of the moral ideal, but rather, in the compromises each is willing to make to moral realism ( $\mathrm{N}$ issen, 1987; Finley, 2001) and in the juxtaposition of ends and means. Inter-cultural education addresses issues of prejudice and injustice - in order to achieve harmonious cultural pluralism. Anti-racist education addresses issues of cultural pluralism and moral relativism - in order to achieve a cacophonous social justice (in the sense of $\mathrm{H}$ abermas, 1990).

The I ndividual and the cultural

While current theories of child development acknowledge the culturally relevant differences among children (cf. O gbu, 1992, Saxe, 1990), as well as individual personality differences and multiple intelligences (cf. Gardner, 1987), there is agreement that certain universals broadly describe epistemological stages (Inhelder \& Piaget, 1958; Kuhn, 1989). This brings us back to Flint's, the corner barbecue take-out.

In the beginning I sketched a picture that I hope evoked sounds, smells, and perhaps for some of you, the memory of a taste. When you think now of I ntercultural, anti-racist education, I hope you can see the lines of students, the happy families dressed for Sunday dinner. I hope you hear reggae music, and smell hot links, wurst, saucisse. Because, at the end of the day, I will argue that developmentally, intercultural understanding in a pluralist democracy starts with just such sensori-motor experiences. 
Target Questions for I CARE

In this paper I suggest that attention to the developmental needs of targeted learners provides clear responsible and effective guidelines for restoring the moral leadership of public schools in preparing children for democratic citizenship. In the next section I address the following questions:

1. H ow does genetic epistemology inform our theory, practice and assessment of inter cultural, anti-racist education?

2. W hat are the moral aims of inter-cultural, anti-racist education?

3. How does the target audience for ICARE projects affect our

Choice of educational aims and means?

Genetic Epistemology: The Universals And the Particulars

D evelopmental moral education and genetic epistemology provide a map for navigating the land-mined terrain from pluralism, around the quagmire of relativism, through participatory democracy, toward peace 2 and justice. Further, de velopmental principles provide clear educational (rather than political) guidelines.

Developmental Matching: The principles and practice of I CARE

1. We attend to age/developmental stage of the learners when we design ICARE projects. This honors the way children learn at different stages (Inhelder \& Piaget, 1958) and provides guidelines for mediated learning in the zone of proximal development (Vygotsky,1978).

2. We attend to the cultural context of the learners. ${ }^{3} \mathrm{D}$ ifferent groups take different paths to the same dance floor, depending on where they're coming from. In the following section, I outline the integration of these concerns, be ginning with the principles applicable to the youngest learners. 4

Inter-cultural experiences for sensori-motor babies

Infants and toddlers know the world through their senses. The child's earliest memories are pre-linguistic. They are the sounds, smells, tastes, sights and feel of one's most primitive (open, loving, curious self). Long after one loses one's grandmother, the smell of her kitchen still evokes scenes, stories, and constellations of primary knowing. In this way, the music, the bird songs, the seasons of one's earliest childhood underlie one's own primitive rhythms. To the extent that very young children are afforded the opportunity to experience the comfort of other cultural smells, tastes and sounds, especially in the context of parental acceptance, support, etc., those cross cultural sensori-motor experiences are embedded and accessible for later symbolic reconstruction. Early positive inter-cul- 
tural sensori-motor experience inoculates toddlers against later assaults of xenophobia and racism. We have good feelings about each other when we smell the barbecue at Flints'.

\section{M inority group toddlers 5}

who are allowed, encouraged in bilingual, biculturalism early on likewise have less fear of and resistance to majority culture in adolescence.

\section{M ajority group toddlers ${ }^{6}$}

who have positive experiences with resident minority group children, families, cultures and languages find them familiar and less frightening in middle childhood.

\section{ACTIVITY FOR TEACHERS}

Imagine your grandmother's kitchen. What do you smell?

Recall an early child-hood image of something culturally foreign to you.

W hat feeling is associated with that image/ experience?

W hat reactions (thoughts, feelings, and associations) are connected with that culture when you encounter it now?

H ow does your early experience color your relationship to that culture now?

For sensori-motor learners the sight, sound, smells, taste and feel of various cultural symbols provides the basis for inter-cultural acceptance. Instructor attitudes, feelings and names for experiences guide the youngest children away from negative val uations that are the basis of later prejudice.

\section{Pre-school learners: Sharing symbols, N aming, Framing \& Classifying}

Between three and six years old the child constructs symbols: cognitive, linguistically mediated signals that name sensori-motor experiences. ${ }^{7}$

Picture This! At this age storybooks with multi-cultural images become critical learning tools. Between four and six years old word stories, narratives, are incorporated into doll play, symbolic play and story making that afford the opportunity for ICARE. Stories make sense of feelings and experiences. Children begin to piece together how they know what's true. All of a sudden how things look, smell, taste, sound and feel, are no longer reliable measures. $\mathrm{H}$ ouses look tiny when we fly above them. The moon looks like it's following me home. H ow could the earth be round?

\section{M inority group children}

At this age minority group children first begin to notice the discrepancy between 
their sensori-experience of themselves and the larger society's names for things. «M ommy you and my teacher look the same color, so why are you Black and she's white?» «W hat's an auslander, mommy? I thought we were Portuguese? Tamil? Etc. A five-year-old girl knows that small people get tall, but not that girls can't grow up to be daddies. At this stage we adults are most vulnerable to impose our socially constructed categories and values on children's perceptions by our naming of then. Attention must be paid to the messages in the narratives we teach, the images we portray, the stories we tell, the way we respond to children's questions.

\section{M ajority G roup $\mathrm{Children}$}

$M$ ajority group children, while they may be statistically and socially less likely to experience the discrepancy with respect to themsel ves and their families, are very likely to experience the discrepancy should they voice their curiosity when they encounter the $\mathrm{O}$ ther; (W hy is he brown, mommy? H ow comel don't have curly (flat; orange) hair like Susannah? Why does he wear that funny thing on his head? Why is that woman wearing a long coat in summer? H ow does Kwame know when his hands are clean? W hat's that funny smell?) H ow do we answer such questions? H ow do we encourage and manage natural curiosity in young children? H ow do we validate the perception and experience of cultural difference without devaluing (or idealizing) either self or other? $\mathrm{H}$ ow do we reconcile the moral tasks of truthfulness and respect? 8

\section{Mixed groups of children}

All preschool children should have the opportunity to read multi-cultural story books, see a range of pictures and images from different cultures common in a nation, and near-by; hear and use common words in local languages; play with colored dolls and international dress-ups; choose between forks and chop sticks in the Play house, etc. Children at this age sort and classify naturally. They make comparisons and categories. As instructors, we provide the materials for sorting, and then help children to name the categories and frame the groups. This provides great opportunities for comparing e.g. arm length, hair color/texture, eye color, height, etc. Coins from different nations, beans from different cuisines, musical instruments, all can be sorted, classified, organized. Likewise words in different languages which sound alike look alike or have similar and different meanings help children to make connections. Children should be encouraged to bring family photos and make «me» books (D erman-Sparks, ABC Task force 1998).

\section{Primary School: Heroes and holidays tell our stories}

The most common approach to multi-ethnic, pluralist, diversity education is one which broadens the «standard» curriculum with the addition of the contributions, customs and, occasionally, the perspectives, of a range of people in the world/the nation/the community. It is most frequently, and appropriately, intro- 
duced in elementary school. James Banks (1994), president of the American Education Research Association, and the architect of contemporary multi-cultural education in America, calls this additive approach to pluralism «heroes and holidays.» $\mathrm{H}$ ere, we learn that African-American C rispus Attucks fired the first shots against the British in the American Revolution; that $C$ inco de $M$ ayo celebrates the M exican expulsion of the French with baile folklorico; that Chinese Lunar $\mathrm{N}$ ew Year celebrations last ten days, ending with a dragon dance in the streets; that during Ramadan M oslems refrain from eating during day light hours; that many $C$ hristian cultures celebrate EI D ia de Los M uertos in ways different from $\mathrm{H}$ alloween, and so on. C hildren are encouraged to find similarities in the foods that are rolled in dough in different cultures, and differences in the rhythms of the music of different lands.

\section{Inter-cultural curricula for mixed, minority and majority groups}

In the twenty-first century, we may risk minimizing the revolutionary nature of this $\mathrm{H}$ eroes and $\mathrm{H}$ olidays addition to the Western canon. We must acknowledge, however, that in the 1960s and 70s even H eroes and $\mathrm{H}$ olidays would have been deemed heresy. M any of us were arrested, expelled or denied credentials or tenure for daring to suggest that the experiences of minorities and women should be included in social studies, literature and art classes. As recently as twenty years ago «World history» in the C alifornia state curriculum traced «civilization» from G reece and Rome, through western Europe, and thence, aboard Spanish and British ships, to N orth America. California children were not exposed to China, India, Africa or South America as part of the civilized world until they entered middle school at age twelve. This was true of both Euro-American (majority group) children and children whose fore-parents came from Asia, Africa and South America.

\section{M inority G roup children}

Afro-centric curriculum projects (Asante, 1987) are the most common contemporary examples of culturally based curricula designed to raise the levels of competence, confidence and self-esteem of minority group children, so that minority group children are better equipped to participate as equals in a democratic society. An Afro-centric curriculum, as the name implies, looks at the development of world history, for example, from the point of view of how Blacks affected that history, and how that history effected blacks. It offers, as well, an African pedagogy based on analogical, metaphoric, collectivity, rather than anaIytic, scientific, linear competition which, it is argued, characterizes traditional (i.e. Euro-centric) educational projects. Some single-sex women's studies projects, likewise, use a feminist pedagogy as well as a womanist curriculum to «empower» girls to become healthy adult women, fully participating, even civilizing partners in the democratic endeavor. Genetic epistemology suggests that in minority schools such Black Pride, Frauen Power curricula do indeed foster the de- 
velopment of a positive attitude toward school and learning and a concomitant sense of the child's inclusion as a competent learner. Bilingual, bilteracy projects also seem to effectively prepare immigrant children for integration and participation in the dominant/host culture, while encouraging the retention of children's «home culture» and their attachments to family/community (SuarezO rozco, 2001).

The pedagogical error in the use of such Afro-centric projects is to introduce them in middle school, when children are struggling with issues of personal and cultural identity. Developmental psychology would suggest that intra-cultural projects are effective before middle school, as an inoculation against the onslaughts of a negative identity (M ead, 1934).

$\mathrm{N}$ ote well that $\mathrm{H}$ eroes and $\mathrm{H}$ olidays curricula prepare children for the identity conflicts coming in adolescence. Just as 3 to 5 year olds should be exposed to language, to stories, to books in order to prepare them to learn to read when they have the cognitive capacity to coordinate symbols (typically between 5 and 7 years old); so exposure to the heroes, holidays, customs, history and traditions of various cultures, prepares primary school children to coordinate identity and community, self and other, when they have the cognitive capacity (and social demands) to do so, (typically between 12 and 15 years old) (Selman, 1980).

U nfortunately, single sex schooling, Afro-centric curriculum, and culturallybased pedagogies are too often implemented in middle school, when children are 12 to 14 years old. At that age, children are likely to use such ICARE projects to calcify or foreclose (E rikson, 1968) their ethnic identity, rather than to question, try on and construct genuine, fully conceived identities.

\section{Majority group children}

The stories of our nation. The belittled $\mathrm{H}$ eroes and $\mathrm{H}$ olidays curriculum is useful in majority group elementary schools for creating the opportunity for a sense of history (her-story, my-story), and as a basis for building shared narratives. Concrete operational children need concrete information. Both majority group and minority group children need to learn these things in public school settings in order to be able to share and validate their understandings with others.

Playwriting is a wonderful tool for children at this age. They can use their story books or characters and settings from «popular culture» to create and enact their own stories. Instructors provide guideline for story development and guide the children in discussing various roles played by/given to different characters, encouraging children to play roles that are different from their experiences of themselves, as well as similar; and to reflect on those experiences.

\section{Mixed groups of children}

$C$ reating shared narratives is a critical tool at this age. Social studies texts that celebrate pluralism both in content and in perspective are important tools throughout primary school. Evaluate the maps we use to teach geography. Are they Euro- 
centric? D oes that effect the perception of size, distance, relationships among the nations?

It is not appropriate to teach Black history only to Black children; for Japanese children to learn Japanese culture in after-school Japanese schools. Children who share a community need to validate their understandings of the world with one another. It is critical that children of a particular culture be taught the heroes and holidays, history and values of their own culture, for the sake of their self-esteem, sense of competence and sense of historical continuity and consequent responsibility. It is equally critical for majority group children to share that knowledge base. 0 nly in this way can middle school children in pluralist democracies construct a shared narrative that will ultimately guide the reformation of their shared democracy.

\section{Heteronomous morality and making a friend in youth.}

Primary school is the time when children develop a heteronomous morality (Piaget, 1932). In simple terms, heteronomous morality is that democratic ideal of equals agreeing on rules of fairness. This moral challenge demands concrete operational thought, perspective taking, and, usually, a same age peer (Selman \& Schultz, 1990). These developments both facilitate and are facilitative of friendship. At this age friends construct the rules of the game, which later form the basis for a group identity. «We don't play that way! We count to twenty; we have to touch the wall before we turn; we don't use steelies.» C hildren need the opportunity to make and construct rules in the company of equals. Piaget noted that children all over the world spontaneously make rules in their games. ${ }^{9}$ In intercultural settings it is particularly important that teachers encourage and guide discussion of rules (and their reasons) in non-threatening contexts. This creates the forum to address issues of prejudice and discrimination should they arise. W hen new games or projects are introduced, teachers encourage children to discuss and agree on the rules in advance of the game/project. Are one-eyed jacks wild? W hat happens when the ball hits the line?

Rule bound games where children have the opportunity to play together and resolve interpersonal conflicts in cross-cultural settings provide valuable practice for navigating the troubled waters of adolescence. M ixed-group primary schools are ideally situated to instruct children in the practice of conflict resolution.

Early Adolescence. Who Am I and where do I belong?

The co-incidence of identity and morality in early adol escence.

Anyone who has ever taught children between 11 and 14 knows its tumult. Just when youngsters are at their most awkward, pimple-faced stage, their body parts 
growing at unpredictable rates, - they ironically gain the cognitive capacity to see themselves through the eyes of others; to want to find their place in the society of their peers; to leave their families of origin and join the world of adults. This universal developmental transformation is difficult in the best of circumstances. M inority status complicates the passage (Blakeney \& Blakeney, 1992; Ward, 1990). For adolescents who construe their families as part of the dominant culture, there is no discontinuity of social context among home, school, and thelarger society. For minority group youth the transformation provides the risk of excluding (home, family, culture of origin) or being excluded (from the dominant culture, the society of possibility, the mainstream). H ow do we help? Again, this depends largely on learner characteristics.

\section{M ixed groups. Intercultural understanding in interpersonal context}

For mixed groups of students, we have to be aware of the variation in rates of cognitive development; and the sensitivity of the students themselves. Recommended instructional activities for this age (roughly 11-13) are community based peer pair research projects, where assigned pairs work together to present projects constructed in teams or small groups. Such projects could be based on field research, library research (primary sources), or project development (e.g. art, music, dance, hand-crafts, etc. They should include some important aspects that make use of non-linguistic ways of knowing. These projects should cover aspects of various cultures in concrete ways, and in ways where each member of the pair islearner, and each is instructor, as well as projects where both partners learn together about another culture unfamiliar to both. Science projects are a valuable opportunity to create cross cultural pairs in neutral territory.

Tolerance as an antidote to racism, xenophobia and intergroup violence?

Facing $\mathrm{H}$ istory and $\mathrm{O}$ urselves (FH AO) is a program designed to «engage students of diverse backgrounds in an examination of forms of intergroup conflict (racism, prejudice, antisemitism) in order to foster perspective-taking, critical thinking and moral decision making, and to help students develop into humane and responsible citizens.» (Schultz, Selman \& Barr 2001).

In their recent evaluation of the effectiveness of FHAO; Schultz, Selman and $\mathrm{H}$ ickey (2001) found that the curriculum was most effective in reducing racism, ethnic identity calcification and fighting among non-minority group, non-fighting girls. The curriculum is designed to make it safe to reflect on, discuss, disagree and re-solve conflicts where cultural/racial/group differences are an issue. The project (this time conducted in 14 eighth grade classrooms) was less effective at reducing prejudice among boys; reducing intergroup antipathy and fighting among boys who fight; and reducing ethnic identification among minority group children. In other words, the group most likely to benefit from this specific, widely used curriculum project, are those students who are developmentally ripe and socially well located to make use of the curriculum which has been taught. 
I suggest that the failure of $\mathrm{FH} \mathrm{AO}$ to achieve its goals in this project is related to just the developmental concerns we have outlined. The fourteen year olds in the project were devel opmentally unable to generalize from the abstract vignettes and historical narratives, to the concrete interpersonal situations when the context was emotionally charged and related to nascent identity development. O Ider adolescents, for whom FH AO was designed are developmentally better equipped to make use of the program.

\section{Secondary Schools: Preparing teens to join a community of equals}

Adolescents reach «high school» in the US at fourteen or fifteen years old. M ost high schools, particularly urban schools, track students for university, post-high school vocational training, or the world of work (or, too often, to the street corner). Tracking in the US is largely a reflection of race and class. By secondary school, more than $85 \%$ of U S schools are predominantly (75-100\%) minority -or predominantly majority (Suarez-O rozco, 2001). What ICARE lessons are most hel pful in preparing these mostly segregated students for participation in a pluralist, democratic community of equals? $\mathrm{H}$ ow can we best prepare culturally diverse adolescents for civic life?

\section{Minority group teens}

We have said that the tension between respect for cultural pluralism, on the one hand and social cohesion on the other is perhaps the single most resonant moral question we face as citizens.

In schools that remain majority $M$ inority are we to strive for the assimilation of $M$ inority group youth into $M$ ajority culture or are we to strive for the moral ideals of the M inority culture itself, when those come in conflict with the M ajority culture?

Is the goal in the secondary school fluency, literacy in the language and culture of the $M$ ajority or of the M inority (when the two come in conflict)?

D o we teach Black youth to see themselves through the eyes of the $M$ ajority culture or do we teach them to resist demeaning stereo-typing? If resistance, do we teach them to strive for full equal inclusion, or a separatism which allows them individual personhood, but suggests separatism?

And what of M oslem women and girls?

While a nation, its adults and the instructors of its children must have this discussion, the specific teaching of the steps of this dance, the process of both political and moral discussion in multi-cultural perspective, is reserved for secondary school. Adolescents themselves are best brought into the larger dialogue from about age fourteen on. The de facto segregation of our schools into immigrant and native born, citizens and non-citizens, hyphenated residents, and ethnic, religious enclaves poses a particular moral and political challenge. $\mathrm{O}$ the one hand, as a democracy we have agreed on a particular goal along the conti- 
nuum single people - pluralist nation (think «Yugoslavia», «R wanda», « ndone sia»). On the other hand, the state takes as its responsibility the education of all children.

The lesson suggested by the ICARE curriculum is that in the secondary schools, when young people are presumably capable of formal operational thought, multiple perspective taking and abstract moral reasoning the youth themselves must be brought into the conversation. W hile there must be a shared canon (along the lines of Cultural Transmission), there must also be a devotion to the conversation and a tolerance for its noise. D emocracy demands discourse. It is the role of the school to shape the conversation and provide the forum for the argument, and the rules for engagement. Secondary schools can only succeed in preparing young people for democratic citizenship by providing them the opportunity to practice democracy. This is as true for majority $M$ inority schools as it is for $M$ ixed and $M$ ajority schools. The role of the instructor is to raise the questions.

\section{Majority group teens}

$M$ uch has been written about teaching tolerance in majority $M$ ajority schools. The paradoxical white studies movement (Sheets, 2000) in the U S and Western Europe is one recent attempt to address the privilege of the pale skinned over the colored people of the world. D wight Boyd has brilliantly undressed the hidden curriculum in the «tolerance» approach to diversity: Tolerance assumes paternalism. M ajority group secondary students must be exposed to multiple perspectives and must be taught (or encouraged) to question the dominant paradigm. $M$ astering a field in order to question and go beyond can be fashioned in such a way as to rechart the course of a river, rather than allowing it to overflow its banks, or dry up, in the words of Langston $\mathrm{H}$ ughes, like a raisin in the sun.

\section{Mixed group secondary schools}

$M$ ixed secondary schools hold the promise and the problems of the future. Are they temporary holding places while one population supplants another? Or are they the future? In the US the very act of segregating and integrating schools has been seen as the means to achieving democratic equality, perhaps at the cost of pluralism. (The goal of integrating schools, after all, was the melting pot, a sort of fondue mélange - as contrasted with the salad bowl or the mosaic). O ne re cent thrust in $\mathrm{N}$ orth American schools has been to redefine pluralism away from the cultural and toward the ontological. The magnet schools approach is de signed to bring together students from a variety of cultural/ethnic/racial/religious backgrounds who share a common interest in science, art, music, languages, technology, vocations, etc. in a school organized around excellence in a particular area. So far the outcome of these schools in preparing youngsters for life in a democracy is promising. Charter schools and vouchers are another movement toward pluralism (parental control of educational choice). The out- 
come of these efforts remains to be seen. The privatization of public schools in the US has, so far, proved disastrous.

\section{Su mma r y}

In this paper I have outlined a developmental approach to Inter cultural, antiracist education. The developmental approach is designed to build on children's naturally emerging logical, social and moral tasks in order to create experiences and reflections that will build

$\checkmark$ a true and good understanding of themselves;

$\checkmark$ the competence and desire to take the perspectives of others who are similar to and different from the self;

$\checkmark$ an understanding and respect for others as individuals and as members of their self-chosen cultural identities, and

$\checkmark$ the ability to discuss and resolve problems of conflicting moral claims when those claims include the perspectives and concerns of the culturally and/or socially different other.

The goal of ICARE projects, then, is to help children who live in multi-cultural/plural democracies to have the capacity and desire to see, address, discuss and resolve problems which may arise among themselves as fully participating members of a community of equals. In this way, a developmental approach provides morally justifiable guidelines for sound pedagogical practice with children from preschool through high school. It takes into account children's increasing capacity for thinking broadly, creatively and critically; their capacity for role-taking with individuals, groups, abstract others and even antagonistic others; and the particular developmental moral tasks that are appropriate to each age group. Further, a developmental approach takes into account the children's social world as it is, and the world, their communities and nations, in the (unknowable) ways they may become.

Not es

1 Portable CD/tape player, preferably with a loud bass

2 I want to thank $G$ avriel Sal omon for reminding me that justice without peace is but a temporary truce.

$3 \mathrm{H}$ ere we distinguish among majority $\mathrm{M}$ ajority classrooms, majority $\mathrm{M}$ inority classrooms, and mixed groups. We leave it to the individual schools, instructors to sketch the most accurate cultural atmosphere of the classroom for this purpose.

4 The principles of genetic epistemology to which I refer are particularly taken from Piaget. I also attend to the socio-moral applications of Piagetian constructs as elaborated by Wolfgang Kohlberg (1986), Selman (1980) and Kegan (1982). I am grateful for their support, encouragement and hard questions over the years.

$5 \mathrm{M}$ inority, here and elsewhere, refers to those who perceive themsel ves and are perceived by others to be outside the «dominant» group. 
$6 \mathrm{M}$ ajority here and elsewhere when it refers to a Cultural/ethnic group refers to members of the «dominant» cultural group, either in terms of numeric majority, historic majority, or power majority.

7 The easi est way to understand this is to re-call a word-sound like «lemon.» D oes it make your mouth pucker? W hen I say orange, can you smell it? D oes the name of your favorite mountain call to mind stories from your many hikes and ski-trips?

8 n.b. D o not assume that five year olds share semiotics with adults. W hen our son was five years old a cousin got married. «W here's the wedding, Daddy?» he asked. «At the new Black church in East $\mathrm{O}$ akland,» his father answered. When we pulled into the parking lot our son looked puzzled: «W here is the Black church D addy? I only see a yellow church.»

9 Piaget famously (and I thought racistly) wrote «even N egro children play marbles» and even then, he didn't mean N egro girls.

Ref erences

Asante, M. K. (1987). The Afro-centric I dea. Philadelphia: Temple University Press.

Banks, J.A. (1994). M ultiethnic Education: Theory and Practice (Third Edition) Boston: Allyn $\&$ Bacon.

Banks, J.A. \& Lynch, J. (Eds.). (1986). M ulticultural Education in Western Societies. London: C assell.

Blakeney, C.\& Blakeney, R. (1992). The role of Racein M oral Reasoning. In D .K. Lapsley \& F.C. Power (Eds.), The Challenge of Pluralism: Education, Politics and Values. South Bend, IN : N otre D ame Press.

Blakeney, R.F. (2000). Invitation to the D ance: Citizenship, migration and minority status. Paper presented at the 19th annual meeting of the Association for M oral Education, Glasgow, Scotland.

Boyd, D. (1996). Dominance Concealed as Diversity. Harvard Educational Review, 66, 3, 609-630.

Carmichael, S., \& H amilton, C.V. (1967). Black Power: The politics of Liberation in America. N ew York: Vintage.

Castles, S. \& D avidson, A. (2000). Citizenship and migration: Globalization and the politics of belonging. N ew York: Routledge.

D amon, W. \& H art, D . (1986). Self U nderstanding in Childhood and Adolescence. N ew York: Cambridge University Press.

D erman-Sparks, L \& the ABC Task Force. (1998). Anit-Bias Curriculum: Toolsfor Empowering Young Children. Washington, D.C.: National Association for the Education of Young Children.

DuBois, W.E.B., (1903/1961). Souls of Black Folk. N ew York: Fawcett Publications.

Erikson, E.H. (1968). I dentity, Youth and Crisis. N ew York: W.W. Norton \& Co.

Finley, M . (2001). M oral Psychology and Spirituality. Lecture Series, U niversity of Judaism.

Fox, R. (1971). The Guardian of B oston: William M onroe Trotter. Scribner: N ew York.

Freire, P. (1973/1993). Pedagogy of the 0 ppressed. N ew York: The C ontinuum Publishing.

Gardner, H . (1987). D evel oping the Spectrum of H uman Intelligences. H arvard Educational Review, 57, (2), 187-193.

Gay, G. (1982). D evelopmental prerequisites for M ulti-cultural Education in the social studies. In L.W. Rosenzweig (Ed.), D evelopmental Perspectives for M ulticultural education in the social studies. Washington, D.C.: N ational Council for the Social Studies.

Gibson, M., \& O gbu, J. (Eds.). (1991). M inority Status and Schooling: A comparative study of immigrant and involuntary minorities. N ew York: Garland.

Gilligan, C., H ammer., T. \& Lyons, N . (1990). M aking Connections. The Relational W orlds of Adolescent Girls at Emma Willard School. Cambridge, M A: H arvard U niverstiy Press. 
Gollnick, D .M . (1980). M ulti-cultural Education. Viewpointsin Teaching and Learning, 56, 1-17. H abermas, J. (1990). M oral C onsciousness and Communicative Action. C ambridge, M A: M IT Press.

$\mathrm{H}$ aste, $\mathrm{H}$. (2001). The N ew Citizenship of Youth in Rapidly Changing $\mathrm{N}$ ations. H uman De velopment, 44, 375-381.

Inhelder, B. \& Piaget, J. (1958). The Growth of Logical Thinking from Childhood to Adolescence. N ew York: Basic.

Katz, M . (1983). Poverty and Policy in American H istory. N ew York: Academic Press.

Kegan, R. (1982). The Evolving Self. C ambridge, M A: H arvard University Press.

King, M.L. (1968) Public Address.

Kohlberg, L. (1986). The Psychology of M oral D evelopment. N ew York: $H$ arper \& Row.

Kuhn, D . (1989). Children and adults as intuitive scientists. Psychology Review, 96, 674-689.

Lagemann, E.C. (1979). A Generation of women: Education in the Lives of Progressive Reformers Cambridge, M A.: H arvard U niversity Press.

May, S. (1999). Critical Multiculturalism: Rethinking multicultural and antiracist education. London: Falmer Press

M ead, G.H . (1934). M ind, Self and Society. Chicago: University of Chicago Press.

N ieto, S. (2000). Affirming Diversity: The socio-political context of Multicultural Education. (Third Edition). N ew York: Longman

N issen, M. (1987). M oral Norms and Social Conventions. Developmental Psychology, 23 , 719-725.

0 gbu, J. (1992). Le frontières culturelles et les enfants de minorités. Revue francaise de pédagogie, 101, 9-26.

O ser, F., Dick, A. \& Patry, J.-L. (Eds.). (1992): Responsible and Effective Teaching. The N ew Synthesis. San Francisco: Jossy Bass.

Pacheco, A. (1977). Cultural pluralism: A philosophical analysis. Journal of Teacher Education, $28,16-20$.

Perkinson, H . (1968). The imperfect panacea: American faith in Education, 1865-1965. Random H ouse: N ew York.

Piaget, J. (1932). The M oral Judgement of the Child . Glencoe, IL: Free Press.

Piaget, J. (1981). Intelligence and Affectivity: Their Relationships D uring Child D evelopment. Palo Alto, CA: Annual Reviews.

Rawls, J. (1971). A Theory of Justice. C ambridge, M A: H arvard U niversity Press

Savin-W illiams, R.C. (1980). D ominance hierarchies in groups of middle to late adolescent males. Journal of Youth and Adolescence, 9, 75-85.

Saxe, G . (1991). Culture and Cognitive D evelopment: Studies in M athematical understanding. $\mathrm{H}$ illsdale, N .J.: Lawrence Erlbaum Associates

Schultz, L.H ., Barr, D .J. \& Selman, R. (2001). The Value of a D evelopmental Approach to Evaluating Character D evelopment Programmes: an outcome study of Facing $\mathrm{H}$ istory and O urselves. Journal of M oral Education, 30, (1), 3-27.

Schweder, R., M ahapatra, M . \& M iller, J. (1987). Culture and M oral D evelopment. In J. Kagan \& S. L amb (Eds.), T he emergence of M orality in Youg C hildren. Chicago: University of Chicago Press.

Selman, R. (1980). The Growth of Interpersonal U nderstanding. N ew York: Academic Press.

Selman, R. \& Schultz, L.H . (1990). M aking a Friend in Youth: D evelopmental Theory and Pair Therapy. Chicago: U niversity Press.

Sheets, H .R. (2000). Advancing the Field or Taking Center Stage: The W hite M ovement in M ulticultural Education. Educational Researcher, 29, (9), 15 - 20.

Skinner, B.F. (1953). Science and H uman Behavior. N ew York: M acmillan

Slavin, R.E. (1979). Effects of Biracial Learning Teams on Cross-Racial Friendships. Journal of Educational Psychology, 71, 381-387. 
Sleeter, C. E., Grant, C. (1987). An Analysis of M ulticultural Education in the United States. $\mathrm{H}$ arvard Educational Review, 57, (4), 421-444.

Suarez-O rozco, C. (2001). Afterward: Understanding and Serving the Children of Immigrants. H arvard Educational Review, 71, (2) 579-589.

Suzuki, B.H. (1984). Curriculum Transformation for Multi-cultural Education. Education and U rban Society, $16,294-322$.

Tyack, D.B. (1974). The O ne Best System. C ambridge, M A: H arvard University Press.

Vygotsky, L. (1978). M ind in Society: The development of higher psychological processes. C ambridge, M A: $\mathrm{H}$ arvard U niversity Press.

Ward, J.V. (1990). Racial Identity Formation and Transformation. In C. G illigan, N . Lyons \& T. H anmer (Eds.), Making Connections. The Relational World of Girls at Emma Willard School. Cambridge, M A: H arvard University Press.

Watson, J. (1930), Behaviourism, (2nd edition). N ew York: N orton.

Weinberg, M. (1977). M inority Students. A research appraisal. Washington, D .C.: U .S. G overnment Printing 0 ffice

Whiting, B.B., \& Edwards, C.P. (1988). Children of D ifferent Worlds. The Formation of social Behavior. Cambridge, M A: H arvard University Press.

\section{Wie soll man wissen, ob dies eine gute Sache ist? Ein entwicklungsorientierter Ansatz für die interkulturelle, antirassistische Erziehung}

\section{Zus a mmenf as s ung}

D as Spannungsverhältnis zwischen kulturellem Pluralismus und sozialer Kohäsion ist vielleicht das einzige nachhaltige, moralische Paradox heutiger D emokratien. Von dieser H erausforderung ist die öffentliche Erziehung stark betroffen. Nordamerikanische Projekte der interkulturellen und antirassistischen Erziehung der letzten vierzig Jahre hatten jedoch nur beschränkten Erfolg. D er vorliegende Beitrag führt dies darauf zurück, dass solche Projekt unter einer ge trübten moralischen Vision und unter einer pädagogischen Indifferenz gegenüber den Entwicklungsstadien von Kindern und Erwachsenen als Lernenden ge litten haben. D er Beitrag beschreibt zwei unterschiedliche moralische Ziele der Erziehung zur demokratischen Staatsbürgerschaft. Er zeigt, dass das Spannungsverhältnis zwischen diesen zwei Ansätzen aufgelöst werden kann, indem auf die Entwicklungsbedürfnisse verschiedener Gruppen von Lernenden Rücksicht genommen wird. Auf diesem $\mathrm{H}$ intergrund wird ein entwicklungsorientierter Ansatz einer interkulturellen, antirassistischen Erziehung skizziert. 


\section{Comment savoir si cela une chose de valeur : une approche développementale de l'éducation interculturelle et antiraciste}

\section{Rés umé}

La tension entre pluralisme culturel et cohésion sociale est peut-être le paradoxe moral à la plus forte résonance des démocraties contemporaines. Le défi n'est pas moins intimidant pour le système éducatif public. $D$ ans les dernières quarante années, les projets nord américains dans le domaine de l'éducation interculturelle et del'éducation anti-raciste ont rencontré des succès limités. L'argument de cet article est que ces projets ont souffert d'une vision morale manquant de clarté, ainsi que d'une indifférence de la pédagogie à la prise en compte des stades du développement des enfants et des adolescents comme apprenants. La présente contribution décrit deux objectifs de l'éducation à la citoyenneté démocratique, bien distincts l'un de l'autre. II développe l'argument selon lequel la tension entre ces deux approches peut être réduite en se référant aux besoins développementaux des différents groupes d'apprenants. Les contours d'une approche développementale de l'éducation interculturelle et antiraciste sont proposés.

\section{Come giudicare se una cosa è buona: un approccio evolutivo all'educazione interculturale e antirazzista}

\section{Ri as sunt 0}

La tensione tra pluralismo culturale e coesione social è forse il paradosso morale più appariscente delle democrazie conteporanee. Q uesta sfida ha effetti scoraggianti per l'educazione pubblica. I progetti nordamericani per un'educazione interculturale e antirazzista hanno avuto scarso successo negli ultimi quarant'anni. In questo contributo si ipotizza che questi progetti siano stati condizionati da una visione morale poco chiara e dalla mancata considerazione delle fasi di sviluppo degli allievi. In seguito si descrivono due distinti obiettivi dell'educazione morale alla cittadinanza democratica e si accredita la possibilità di superare la tensione tra i due approcci a condizione che si tenga conto delle esigenze derivanti dallo sviluppo dei vari gruppi di allievi. Di conseguenza si delineano i contorni di un modello evolutivo di apprendimento interculturale e antirazziale. 